\title{
Inspiring advocacy: Abraham Jacobi
}

\section{Richard B. Gunderman ${ }^{1}$}

Received: 28 July 2019/Revised: 28 July 2019 / Accepted: 5 September 2019 /Published online: 9 October 2019

(C) Springer-Verlag GmbH Germany, part of Springer Nature 2019

One of the most precious resources for physician advocates is inspiration. Funding, equipment, facilities and personnel all have a role to play, but unless our words and actions are inspired, our efforts can fall flat. One of the best sources of inspiration is biography - the stories of the careers and lives of predecessors who overcame poor resources, surmounted barriers, built alliances and promoted a vision that made a difference for patients, colleagues and society. One of the most inspirational advocates in pediatrics - yet a man whose work remains largely unknown to many in our field - is Abraham Jacobi, who died 100 years ago and is often called the father of American pediatrics [1].

Jacobi was born in Germany in 1830 to a family of humble means. A sickly child, his parents nearly despaired of his survival, but his mother never gave up, and she insisted that he receive a good education. As a young man, Jacobi attended several German medical schools, graduating from Bonn in 1851. Traveling to Berlin to complete his examinations, he was arrested and accused of treason, because he had been implicated in revolutionary activities. The charges were not baseless, for Jacobi had been a member of Karl Marx's Communist League, and as a result he ended up spending 2 years in prison, at times in solitary confinement, before escaping with the help of a captor.

After his flight, Jacobi traveled to England, where he stayed with Marx and Friedrich Engels. A falling out with Engels made it difficult for him to establish a medical practice in England, so Jacobi emigrated to the United States [2]. There he set up practice in New York's Bowery, where he charged 25 cents for an office visit and 50 cents for a house call. He also began translating medical articles, especially ones focusing on

Richard B. Gunderman

rbgunder@iu.edu

1 Department of Radiology,

Indiana University School of Medicine,

702 North Barnhill Drive, Room 1053,

Indianapolis, IN 46202, USA the diseases of children, which were published in the New York Journal of Medicine. By 1860, he had published his first book on the diseases of women and children, which in turn led to his first academic appointment at the New York Medical College.

Almost no time elapsed before the advent of the Civil War, which led to the school's closure. Jacobi persisted, however, and soon founded perhaps the first free pediatric clinic in the United States. In doing so, he was motivated both by a desire to meet the health care needs of the poor and by the need to enable medical students to move beyond lectures and textbooks to real patients. Like many successors, including Sir William Osler, Jacobi believed that patients are a physician's best teachers, and only by caring for them firsthand could students develop into good physicians.

Yet Jacobi also recognized the limits of a medical career focused entirely at the bedside. Years later, in 1904, he made the case for physician as advocate, writing:

It is not enough to work at the individual bedside in the hospital. In the near or dim future, the pediatrician is to sit in and control school boards, health departments, and legislatures. He is the legitimate advisor to the judge and the jury, and a seat for the physician in the councils of the republic is what people have a right to demand [3].

Jacobi's advocacy sometimes brought him into conflict with his colleagues. For example, he sharply criticized the growing practice of caring for orphans in large institutions. He believed that children could not be raised and cared for on an industrial model, like producing automobiles on an assembly line, and he minced no words in condemning even his own employers. Efforts to dismiss and blacklist him were unsuccessful. Jacobi would not be silenced, arguing that "the younger the child and the larger the institution, the surer is the death" [3].

Jacobi's words were not wasted. In 1870, he was appointed to a faculty position at Columbia College of Physicians Surgeons, and the next year, he was named the inaugural chair of the Section on Pediatrics of the American Medical Association. Yet as titles and honors accumulated, Jacobi 
never wavered in his dedication to the care of patients and the improvement of living conditions in his community. Many faced lives of poverty, overcrowding and poor sanitation, and Jacobi recognized such conditions as roots of disease no less important than lack of medical care. His views were further vindicated in 1877, when he was appointed chair of the New York State Board of Medical Examiners.

Jacobi's personal life was marked by heartbreak [4]. His first two wives died in childbirth. He met his third wife, Mary Putnam, the daughter of a well-known publisher and herself a physician, when she was elected to membership in the New York Medical Society, while he was serving as its president. Putnam had been one of the first women in the United States to receive a medical degree and the first American woman to study medicine at the University of Paris. Their marriage produced three children, only one of whom survived to adulthood. Their son died at age 7 of diphtheria, a disease on which Jacobi wrote a great deal. Putnam died in 1906 from a brain tumor.

In 1888, Jacobi was elected the first president of the first U.S. medical specialty society, the American Pediatric Society. In his inaugural address, he laid special emphasis on the preventability of many childhood diseases, encouraging his colleagues to play a more active role in promoting improved hygiene and living conditions. He also encouraged members to become more active in medical education and to seek charitable donations to create pediatric hospitals. In 1895 , the year that Roentgen discovered X-rays, Jacobi published a textbook, Therapeutics of Infancy and Childhood, and over the course of his career he authored hundreds of journal articles.

In 1912, at the age of 82, Jacobi was elected president of the American Medical Association, becoming the first foreign-born and Jewish physician to serve in that capacity. Deflecting criticisms that his advocacy for women and children represented a form of socialism, Jacobi insisted that it constituted a physician's professional and civic responsibility. Inspired by his advocacy, a wealthy acquaintance donated money to create a children's wing at the German Hospital. This legacy lives on today in the Jacobi Medical Center, which is one of the largest hospitals in the Bronx and the first in the United States to staff its emergency department with pediatric residents.

Jacobi's strategies as an advocate were diverse. He sought political influence through medical organizations and relationships with legislators and judges. He spoke and wrote prolifically, not only at professional meetings and in the medical literature, but for popular audiences and the news media. He lost no opportunity to distinguish the distinctive needs of infants and children from those of adults. And in his quest to promote the health and well-being of children, Jacobi tapped some of the dominant metaphors of his age, likening the improvement of "physical and mental hygiene" to the "manifest destiny" of the nation.

Of Jacobi's legacy, a colleague wrote in 1900 at a Festschrift in his honor:

It is not alone as a medical man that Dr. Jacobi is worthy of honor. He has also sought to promote the welfare of his fellow-men, as a man and a citizen. He has taught the propriety of physicians taking an interest in public affairs, and has exemplified his teaching by taking an active part in many matters of civic and political importance, serving on public committees, addressing legislative bodies, and urging questions of public policy. ... [So we express the] hope that, though threescore years and ten have passed since his natal day, ripe in years and experience, still young at heart and ardent in work as of yore, he may be spared for many years to reap in profusion the fruits of an arduous and well-spent life [5].

These hopes were not misplaced. Jacobi died in 1919, at the age of 89 . His rich legacy includes excellence in clinical practice, clinical and epidemiological research, organization building, and advocacy for the voiceless, especially children and impoverished people. While the depth and range of Jacobi's contributions lie beyond the means of most contemporary pediatric radiologists, his vision, energy, and determination endure as a source of inspiration. He was a good person who believed that each day represents an opportunity to make the world a better place, and his story reminds us that we, too, are capable of doing more good than we might suppose.

\section{Compliance with ethical standards}

Conflicts of interest None

\section{References}

1. Ligon-Border BL (2003) Abraham Jacobi, MD: father of American pediatrics and advocate for children's health. Semin Pediatr Infect Dis 14:245-249

2. Burke EC (1998) Abraham Jacobi: the man and his legacy. Pediatrics 101:309-312

3. Robinson WJ (1909) Contributions to pediatrics. Critic and Guide Co., New York

4. Haggerty RJ (1997) Abraham Jacobi, MD, respectable rebel. Pediatrics 97:462

5. Huber F, Sondern FE (1900) Festschrift in honor of Abraham Jacobi, MD, LLD. Knickerbocker Press, New York

Publisher's note Springer Nature remains neutral with regard to jurisdictional claims in published maps and institutional affiliations. 